\title{
DEVELOPMENT OF INTELLECTUAL ECONOMY: SOME APPROACHES FOR POLICY ELABORATING
}

\author{
Yuliia Orlovska ${ }^{1}$, Anzhela Cherchata ${ }^{2}$, Olena Kovalenko ${ }^{3}$
}

\begin{abstract}
This research is devoted to revealing the theoretical and practical foundations of the intellectual economy formation in the conditions of post-industrial society transformation. Using the historical method of analysis, the authors has made the comparative assessment of the main approaches to explaining the content, factors and features of the intellectual economy development. It has been proved that the main driving force of economic development in the intellectual economy is knowledge, which simultaneously acts as both a resource and a product, and for that product specific demand at all levels of the economic system has been formed. In our view, the intellectual economy is a type of economic system that, being based on the intellectual capital of society in the conditions of development of modern information technologies and systems, uses, transforms, creates and disseminates information and knowledge in order to ensure the growth of social welfare, international competitiveness of countries and extended knowledge and innovation cycle formation. That is, knowledge is at the heart of the development of the economic system, and, at the same time, is the final product of this system in each cycle of reproduction of the socio-ecological-economic system. The determining direction of the transformations in the intellectual economy is predominantly the creation and consumption of knowledge as a different type of intellectual property, including its materialized form with a high intellectual component. The fact that knowledge and information are not only used as an inexhaustible cognitive resource for the development of production, but also turn into the main types of consumption associated with personal development, as a means of renewing and building up this resource, is the key to the endless progress of the intellectual economy. The special features and principles of development of intellectual economy have been explained in the paper. These features and principles have been suggested to use as criteria for the construction of national programs for the intellectual economy formation, as well as for these programs success estimation. The recommendations for overcoming the barriers to building Ukrainian intellectual economy have been elaborated.
\end{abstract}

Key words: intellectual economy, economic system, capital.

JEL Classification: O34, P12, E22

\section{Introduction}

The current stage of the world economic system development is characterized by intensification of the intellectual capital use and shift of public demand towards the products of creative industries, intellectual services, IT and media products, etc. In these circumstances, information and knowledge play an increasingly important role in the development of post-industrial society. Methodological issues about the country-specific factors of intellectual economy development as well as the scientific and practical tasks about relevant economic policies have been posed to the governments and scholars. The importance of these tasks has been reinforcing by the current trends in the center-peripheral development of the countries, by the development of new world "influence centers" as well as of modern drivers of growth. It is important for governments and academia not only to understand the country's existing and desirable position in the world economic system, but also to formulate basic principles and priorities for strengthening and effectively harnessing the potential of post-industrial growth.

\footnotetext{
Corresponding author:

${ }^{1}$ Pridniprovska State Academy of Civil Engineering and Architecture, Ukraine.

E-mail: juliaorlov@ukr.net

ORCID: https://orcid.org/0000-0003-0966-931X

${ }^{2}$ Pridniprovska State Academy of Civil Engineering and Architecture, Ukraine.

E-mail: acherchataya@gmail.com

ORCID: https://orcid.org/0000-0002-6753-2891

${ }^{3}$ Dnipropetrovsk Scientific Research Institute of Forensic Expertise, Ukraine.

E-mail: ap0005aa@email.ua

ORCID: https://orcid.org/0000-0002-6802-7213
} 
In addition, taking into account the modern course of humanity for sustainable development, economic resources and innovative products must be directed towards environmentally sound growth. All these features have fundamentally changed the structure of the modern postindustrial economic system, which is based on the development of intellectual economy.

A knowledge-based intellectual economy is becoming an economic system that provides economic growth and international competitiveness for countries, and therefore requires an additional investigation about the preconditions and current features of its development. In the other words, the peculiarities of the modern economic system of the post-industrial era should be analyzed by assessing the genesis of the development of its dominant form - the intellectual economy

\section{Preconditions for the intellectual economy development in post-industrial society}

The preconditions that led to the formation and development of the modern intellectual economy should be considered based on the method of historical analysis and, first of all, on the evolution of scientists'views regarding modifications in post-industrial society. In turn, the emergence of the concept of post-industrial society and post-industrial economy has its historical background, an understanding of which is important for the proper perception and use of modern factors of economic growth and social well-being.

The first shifts in scientific circles from material resources to intangible, namely information and intellectual, began to take place at the end of the nineteenth century. Marshall A. in 1890 emphasizes in his papers that knowledge itself is the driving force and the most powerful engine of production. These ideas are developed in the works of Schumpeter J. (1911), in which the scientist notes that it is a particular combination of knowledge is the driving force of innovation and production process. In other words, the transition from industrialism to a new system based on intangible factors of production is gradually being realized.

As for the formation of the categorical apparatus, the term "postindustrialism" itself was introduced into scientific circulation at the beginning of the 20th century (1914) by the scientist Coomaraswamy A., who specialized in research on the preindustrial development of Asian countries. Almost simultaneously the concepts of "post-industrial state" and "post-industrialism" have appeared in the papers of Penty A. 1917-1922. The work of Drucker P. in 1950 was devoted to explaining the main reasons for the transition from industrialism to post-industrialism, in which he began to identify the innovative industries, at the heart of which is knowledge. His ideas were extended by Machlup F. in 1962.
The term "post-industrial society" was first used by the American sociologist Riesman D. in his work "Leisure and Labor in a Post-Industrial Society", published in 1958. However, according to Inozemcev V.L., whose opinion is shared by most modern scholars, D. Risman cannot be considered the author of this term, since he incorporated into the concept the so-called "leisure society", which is different from today's interpretation of the concept of post-industrial society. Therefore, most scholars believe that the term "post-industrial society" was first used and justified by Bell D. in 1959 to refer to a society in which material production loses its leading role and knowledge becomes the main productive force.

In 1965, Bell D. headed a futurological commission in the United States, which developed a prognosis for human development by 2000 (Bell, 1968), and noted that post-industrialism would be the main vector of development. In the interpretation of Bell D., a postindustrial society is a society where serious shifts are taking place: in the economy, a shift from manufacturing to services, and in technology, knowledge-intensive industries begin to play a leading role. Later, this concept was reflected in the work of the scientist "The Coming Post-Industrial Society" in 1973 (Bell, 1973), which gave impetus to the emergence of new theories of post-industrialism.

By the beginning of the 1980th, the point of view on the formation of an information economy in a postindustrial society began to prevail in the scientific community. A number of economists in their works began to note the growing role of information and knowledge in the production of goods and services, which gave them reason to introduce the concept of the information society. In particular, the American economist Martin W.J. defined the information society as a society "... in which the quality of life, as well as the possibility of social change and economic development, increasingly depends on information and its use." Stoun'er T. in 1986 argued that there is a shift from material production to production of services, which is essentially information processing.

Masuda Y. believed that the information society is a society based on informational values rather than material values, and whose economy estimates knowledge capital higher than material capital. According to another economist Kastel's M., the information economy can also be called the global economy. The scientist noted that the economy is informational, because "the productivity and competitiveness of factors or agents in this economy depend, first of all, on their ability to generate, process and efficiently use information..."; at the same time, the information economy is global, because "the main types of economic activity, such as the production, consumption and circulation of goods and services, as well as their components (capital, labor, raw materials, management, information, technology, markets) are 
organized on a global scale, using an extensive network connecting economic agents" (Kastel's, 2000).

At the same time, the other scientists fixes their attention on the categories of knowledge and brings the theory of the knowledge economy (knowledge economy) to the fore. In 1994, Stehr N. introduced the concept of a "knowledge society" as one that actively uses knowledge not only as a resource but also as a product of the economic system. It the papers of Kelly K. "New Rules for the New Economy" (1998) the web of the modern economic system, which is characterized by global transformations, by the management of information, knowledge, intellectual capital and by the emergence of close interconnections between elements of the new system, has been investigated and detailed.

In general, at the end of the XX century, and especially at the beginning of the XXI century, the theory of knowledge economy was actively developed and now, in our opinion, it has become the main theoretical basis of modern concepts of intellectualization of economy. We believe that the development of the methodology of these concepts occurred mostly within the different perceptions of knowledge - whether as a factor of production or as its result (product). The main approaches of scientists, as well as the process of convergence of their thoughts are summarized in Table 1.
It should be noted that scientists for a long time did not consider knowledge and information through the prism of the production function (except for the works of A. Marshall and J. Schumpeter mentioned above). For example, in the 1950th and 1960th Skilbeck and Abramowitz wrote about knowledge as a "human factor" or "technology change", but do not see knowledge and information as a separate factor of production. The change in the perception of this concept was laid by R. Romer in the 1980th, where he began to consider knowledge as an important factor of production, that is, the basis of a knowledge-based economy.

At the same time, a number of scientists offer knowledge not only as a factor of production, but also as a product of relevant intellectual industries. The essence of such a new structure of the economy first appears in the works of P.F. Druker and F. Machlup, who perceive the knowledge economy as an economic activity based on the use of knowledge and with its final product new knowledge, or a certain information product or service. F. Machlup focuses on areas such as education and science, the fields where the intellectual product is "manufactured", and the field of intellectual services and media as such, through which the product is distributed. And it was during this period when the concepts of "knowledge economy" and "knowledge

Table 1

Theoretical background of the role of knowledge in the intellectual economy development: a convergence of approaches

\begin{tabular}{|c|c|}
\hline Knowledge as a factor of production & Knowledge as a factor of production and product \\
\hline $\begin{array}{l}\text { End of the XIX century: Marshall A. writes about } \\
\text { knowledge as "the most powerful engine of } \\
\text { production" }\end{array}$ & \multirow{2}{*}{$\begin{array}{l}\text { Mid-XX century: P.F. Druker and F. Machlup "Industrial economic system, innovative } \\
\text { industries that have knowledge or information at their core"; "knowledge economy as } \\
\text { an economy that both is based on knowledge as a factor of production and has new } \\
\text { knowledge (information product or service) as its final product" } \\
\text { Emphasis on education and science as areas where the intellectual product is produced } \\
\text { and the intellectual services and media through which this product is promoted. It } \\
\text { was during this period that the concepts of knowledge economy and knowledge based } \\
\text { economy were closely intertwined }\end{array}$} \\
\hline $\begin{array}{l}\text { Beginning of the XX century: Schumpeter J. } \\
\text { emphasizes the combination of knowledge as the } \\
\text { basis for innovation, which (Yu.O: in turn)* is the } \\
\text { driving force of production }\end{array}$ & \\
\hline \multirow[t]{3}{*}{$\begin{array}{l}\text { End of the XX century: unlike Skilbeck and } \\
\text { Abramowitz, who perceive knowledge as a "human } \\
\text { factor" or "technology change" and do not see it as } \\
\text { a separate production factor, Romer emphasizes } \\
\text { the need to consider knowledge as important } \\
\text { factor of production. }\end{array}$} & $\begin{array}{l}\text { 1990th: Stehr N. sugest the concept of "knowledge society", which became the basis of } \\
\text { the development of the theory of knowledge economy, the main provisions of which } \\
\text { are set out in the work "Knowledge Society" } \\
\text { The OECD defines a knowledge-based economy as inherently oriented towards } \\
\text { the production, dissemination and use of knowledge or information. A similar } \\
\text { interpretation is provided by APEC }\end{array}$ \\
\hline & $\begin{array}{l}\text { Beginning of the XXI century: Chartland, Brinkley, Tapscott emphasis on inclusion of } \\
\text { IT sphere in the concept of knowledge economy. Triple concept (knowledge, network, } \\
\text { innovation); the concept of the role of highly skilled workers who use knowledge and } \\
\text { information to create an intelligent product. Economy virtualization concept }\end{array}$ \\
\hline & $\begin{array}{l}\text { 2010-th: White, Gunasekaran, Ariguzo. Education, knowledge management and } \\
\text { creativity as elements of economic structure; at the same time, all components of the } \\
\text { structure of the economy are based on IT technologies. } \\
\text { As Shahrazad points out, knowledge becomes the driving force of an economy based } \\
\text { on human, intellectual and social capital (Yu.O: intellectual capital) in the context of } \\
\text { increasing the role of the economy's creativity }\end{array}$ \\
\hline
\end{tabular}

Source: created by the author ${ }^{*}$ here and below - initials of the author: Yuliia Orlovska 
based economy" were most closely intertwined. The OECD (Organization for Economic Cooperation and Development) (OECD, 1996) is considered to make the first attempt to define the category of a knowledgebased economy as being essentially oriented to the production, dissemination and use of knowledge or information. A similar interpretation was provided by APEC (APEC, 2000).

It should be noted that quite often scientists identify these concepts. However, in our opinion, there is a fundamental difference between them. We fully share the opinion of Ivanova V.V. (Ivanova, 2011), who argues that a knowledge-based economy is the type of economic system, having at its core the knowledge and information that is embedded in all sectors of economic activity; instead, the knowledge economy is an sum of sectors of the economy that specialize in obtaining (Yu.O: production and sales) an intellectual product.

With the development of technology, the category "knowledge economy" is beginning to include the field of IT-technologies. Chartland (Chartland, 2006) introduces three key concepts into the concept of the knowledge economy: knowledge, network, innovation. Brinkley, who also perceives the knowledge economy inseparable with the IT, argues that the concept of the structure of such an economy lies in the combination of highly skilled, knowledge-intensive workers and the information technology that ultimately creates the intellectual product. Another important aspect of ITrelated issues, as Tapscott notes (Tapscott, 2014), is the virtualization of the economy.

The interpretation of the structure of the knowledge economy is extended by White, Gunasekaran, Ariguzo. Scientists complement the structure of the knowledge economy with such concepts as knowledge management and creativity. According to Shahrazad (Shahrazad, 2017), information as an expression of knowledge becomes the driving force behind the knowledge economy, based on human, intellectual and social capital, in the context of enhancing the creativity of the economy, which is seen as a key aspect in building a long-term sustainable development strategy.

In our opinion, the term "intellectual economy" includes the connection of categories of knowledge economy; service and information economies; sustainable (socio-ecological-economic) development; creative economy, etc. In our view, the intellectual economy is a type of economic system that, based on the intellectual capital of society in the conditions of development of modern information technologies and systems, uses, transforms, creates and disseminates new information and knowledge in order to ensure the growth of public welfare, international competitiveness of countries and formation of an extended circle of knowledge and innovations. That is, knowledge is at the heart of the development of the economic system, and is the final product of this system in each cycle of reproduction of the socio-ecological-economic system. We propose a schematic diagram of the positioning of the intellectual economy in today's post-industrial society as Figure 1.

The objectivity of the process of the intellectual economy formation and the corresponding challenges to the factors of success of countries' development in modern conditions of post-industrial society requires a more detailed study about priorities and guidelines of the modern government's policy of projecting and administration the processes of formation and development of this type of economy.

\section{Priorities and guidelines for the intellectual economy development}

In view of the arguments set out in the first paragraph, it should be assumed that the intellectual economy has appeared from the intersection of concepts: the economy of knowledge; information economy; green economy (sustainable development economy); bioeconomics; circular economy; SMART-economy; innovative economy; creative economy; economy of intellectual property.

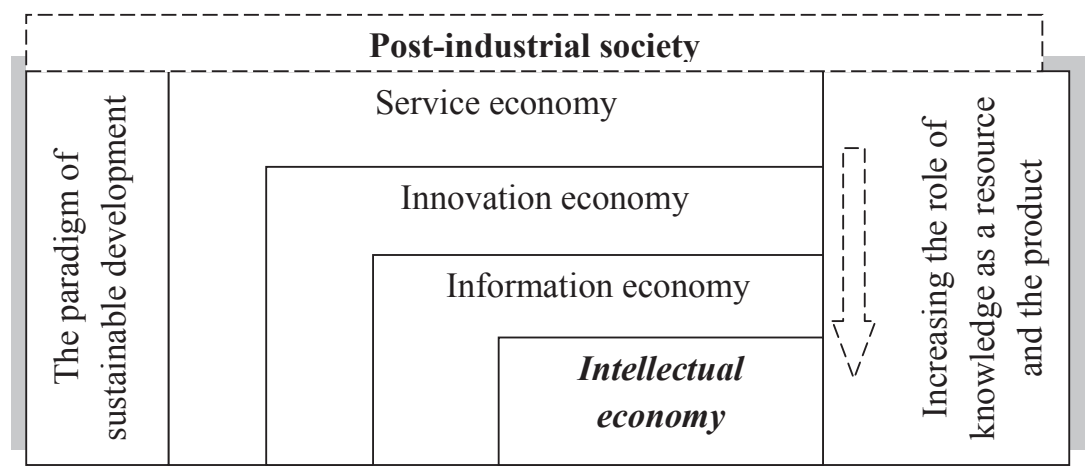

Figure 1. Positioning of the intellectual economy in post-industrial society

Source: created by the authors 
As to understanding the priorities and guidelines for the intellectual economy development as a basis for an appropriate policy elaborating is primarily based on identifying the changes in the demand and production of intellectual products. Regarding to changes in the demand for knowledge as a resource and as a product, Maksimova V.F. (Maksimova, 2011) highlights significant changes in the structure of three types of demand: consumer, corporate and public. She argues that in today's environment, the consumer is in demand for spiritual values. The lifestyle, adequate set and quality of services provided, the organization of business climate, and leisure are important for the members of society. With regard to corporate demand, businesses and organizations are increasingly in need of workers with a wide range of competencies that enable them to meet the challenges of value-adding, labor productivity growth, the generation of new knowledge and their incorporation into production processes, to carry out innovative processes at the local and integrated levels and, as a result, to achieve the stable growth of corporation. On the part of the state the demand for rational use of material, labor, intellectual resources for solving national and global problems is firstly increasing. This refers to changing the nature of labor, enhancing its innovation component, increasing participation in the production processes of intellectual workers, the emergence of firms operating in remote access mode, outsourcing and Smart-sourcing in the commodity and resource markets.

Mokyr J., in turn, draws attention to the role of methods of modern knowledge production and selling. The scientist claims that the transition from traditional to an intelligent economy has arisen due to the fact that information and telecommunication technologies have radically transformed the methods of generating and disseminating the knowledge, significantly reducing the marginal cost of obtaining, storing and transmitting of knowledge.

It is obvious that the adequate use of intellectual resources plays fundamentally important role in the process of solving the problems about the qualitative modernization of the economy, expanding the production of goods and services that meet the requirements of material, labor and energy conservation, could provide innovative development, competitive advantages increasing, sustainable economic growth maintaining, etc. According to experts, the share of intangible assets in the property of large American companies exceeds 50\%; the share of the intellectual capital in the pharmacist cost of production is about 99,5\% (New Zealand Bank).

In modern conditions, intellectual resources are widely used in terms of structural transformations, the creation of fundamentally new forms of entrepreneurship and innovative corporate relations, as well as to increase the competitive advantages of the company. In the USA and in the EU, many companies that practically do not use fixed capital, but only intellectual capital (they are called "knowledge companies" - knowledge companies) have been recently created. Such companies sell knowledge rather than manufacture traditional goods. In the United States, half of fast-growing companies are knowledge companies (Nature, 1999).

Well known professional in the field of management, Druker P.F., claims that while in the 20th century the leadership in the global economy depended on the ability to achieve high physical labor productivity, in the 21 st century this leadership will be transferred to countries that are able to increase the productivity of mental labor most systematically and efficiently. The term "knowledge workers" that means intellectual workers who generate new knowledge has also recently appeared. Florida R. in this regard wrote about the emergence of the creative class and the development of the creative economy.

We propose to consider the intellectual economy and evaluate its development through changes that occur with the main features (characteristic features) of this type of economy (Figure 2). It is possible and necessary to assess: the share of the tertiary and quaternary sectors in the economy; the degree to which processing and recycling are used; the dynamics of the involvement of highly skilled workers in the creation of products of the intellectual economy; the speed and globalization of production and consumption of such products and other indicators. Such kind of criteria and indexes may build the methodological basis for the elaborating the special programs about the formation of intellectual economy in a country.

It should be noted that in some countries such government programs have already been developed. In Ireland, for example (Government Publications, 2008; Preston, Sparviero, 2010), the focus is on creating a world-class research system, on ensuring economic growth through innovation and scientific research, on increasing the country's competitiveness, as well as on developing the green sector of the economy based on the transition from carbon energy using to alternative renewable energy sources using. The problems of actively attracting scientific ideas and know-how, their protection and commercialization, creation of an innovative ecosystem, as well as social protection of the population do not also stand aside. To resolve these problems, some tasks have been put: about increasing the investment into researches, about the formation of a first-class business infrastructure, about the widespread use of human and intellectual capital in the value added creating and innovative goods and services production. The Irish government program focuses on the development of a "green economy" that contributes to the preservation and protection of the environment, to the creation of new jobs in this area and the formation of a special environment for "green collars". 


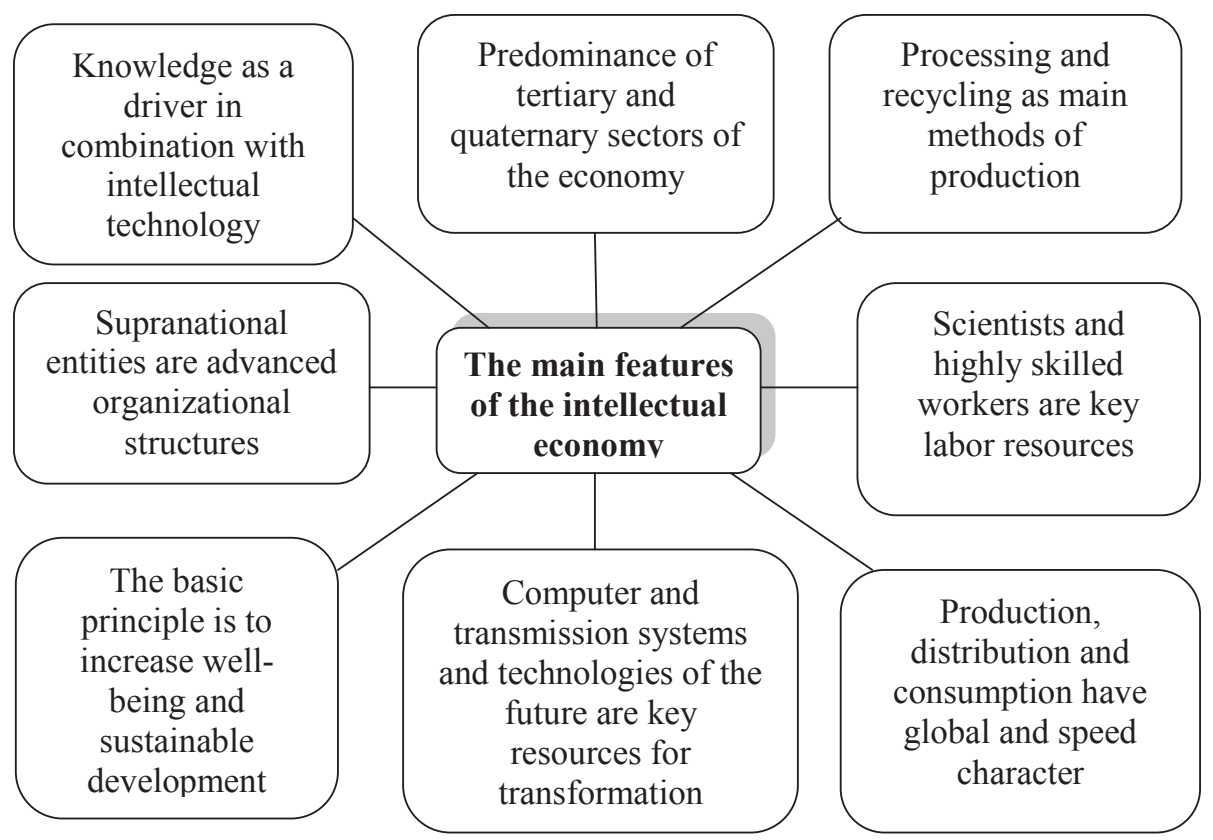

Figure 2. Main features and principles of intellectual economy development

Source: created by the author

It should be considered that the intellectual economy is an economy in which knowledge is acquired, generated, and disseminated in order to enhance economic development. Intellectual economy should therefore be based on four pillars: the education system, information and telecommunications infrastructure, an effective innovation system and the institutional regime. Economic policy guidelines and priorities must be appropriately established. Such guidelines of the policy of intellectual economy development can be called the following:

1. Guideline of intellectualization: it involves the growth of research and development, followed by their introduction into production on an innovative basis; the development of intellectual potential of individuals and enterprises; the creation and development of intellectual needs; stimulation of creativity to the tasks resolving; the constant increase of knowledge in the process of education; the improvement of innovative technologies created on the basis of international standards.

2 . Institutional guideline, which means the activation of the state in the field of structural transformation of property relations; the creation of an effective system of protection of intellectual property rights; the improvement of the legal framework governing research and innovation processes; the promotion of environmental protection of economic entities.

3. Guideline of ecologization: it is aimed at the implementation of environmental and economic interests; the ensuring the integrity of natural systems; the environment protecting its reproduction and rational nature management; the ecological infrastructure improving; the level of ecological culture of the population development.

4. A social guideline: that is aimed at achieving common welfare and collective security in an increasingly interdependent world; at socially oriented coordination of actions; at forming a set of new sociocultural and economic values that ensure the implementation of adequate relationships within civil society; at ensuring the people's confidence about getting a professional education, quality medical care, an adequate job, and access to other social benefits.

The creation and consumption of predominantly not material goods, but knowledge as a different type of intellectual property, including its materialized form with a high intellectual component, has appeared to be the determining direction transformations in the intellectual economy.

It is obvious that on the way to such kind of transformation almost every country faces many barriers which are inherent in Ukraine's regulatory policy as well. In this context, we suggest the set of tools of these barriers overcoming in Ukraine:

To increase innovation potential: the integrated programs of intellectual development (intellectualization), and of international cooperation strengthening in education and science, are required.

To ensure the growth of innovation in strategically important activities: the funding of relevant research through the grant system should be motivated; specialized research centers based on the interaction of the state, business, scientific and educational institutions as well as scientific clusters must be 
established. It is necessary to create conditions for the widespread use of intellectual workers in the process of innovative products and services production. For example, in the UK, at one time, the task about bringing the employment rate of intellectual workers to $40 \%$ or more was put and reached (Brinkley, 2008).

To increase the level of commercialization (capitalization) of innovations: first of all the public-private partnership as well as motivating subsidies and taxation, should be developed; preferential target lending programs might be established.

To enhance the effectiveness of the innovation financing mechanism: creating the programs which could stimulate the development of the financial market and relevant financial instruments to serve the intellectual economy; the stimulating the private, public and public-private venture funds creating.

For the development of intellectual small and mediumsized businesses: the system of regulation of the processes of firms creation and liquidation (in order to accelerate and simplify it), should be reformed; the information support for startups in the field of intellectual business as well as creation of relevant specialized educational platforms must be launched.

To stimulate the inflow of technology from abroad-such set of tools: the protecting investor rights; provision of state guarantees; development of public-private partnership. It is important to create the conditions for the introduction of the latest technologies, Smartnetworks in all sectors of the economy to provide quick access to information and knowledge, generate new ideas with their subsequent implementation in the production of products and services with high added value and intellectual component.

To increase the demand for, and funding for, environmentally-friendly innovations - such set of tools: regulatory support for high-level environmental standards; preferential targeted lending; tax incentives, subsidies and penalties; support for sustainable green investment (green investments); state targeted investment in the development of green activities and intellectual and ecological production. As a result, we should expect the creation and provision of a productive business environment to increase the degree of innovation, and the optimum use of natural, energy and material-saving technologies.

A special role should be given to the development of education, first of all - university education. Kvasniy L.G. and Shcherbak O.Ya. point out that the modern man, who has the relevant knowledge, does not mechanically combine some individual elements, but seeks to ensure that everything takes its place. Therefore, the main principle of the new paradigm is the education development with the purpose not for adequate reflection of the demands of life, but for a radical creative improvement of life; not for responding to the changing needs of society, but for formation of new creative, high-spirited needs, that is, the formation of a new quality of aggregate demand (both as individuals and corporations and states in general).

The modern content of the quality of education is multicomponent. Its main components are: acquisition of new knowledge throughout life; application of modern pedagogical technologies; technical and technological support of the educational process; language policy; creation of a powerful information base of the educational process; national and public education; scientific support for the functioning and modernization of education.

It should be noticed that the scientific and methodological achievements of modern processes of modernization of higher education in Ukraine are already being implemented in the effective work of the National Agency for Quality Assurance in Higher Education, which is reflected in the preparation of a whole corps of experts, consultants, experts and the results of the first accreditation examinations of educational programs. Despite some contradictions in the procedural issues and regulations, as well as the expected resistance from some university and other communities, the process of radical changes in the training of highly qualified personnel has already begun and looks inevitable.

In our opinion, due to the described measures and priorities of economic policy, it is possible to form a selfregulatory mechanism that allows for investments that stimulate the economic development due to maximize the personal consumption, which in the traditional economic theory would previously be considered the antithesis of accumulation and investment.

In the fact that humanity not only masters information as an inexhaustible cognitive resource for the development of production, but also turns the main types of consumption associated with the development of personality into a means of renewing and building up this resource, scientists see the key to the endless progress of post-industrial society. Zahodjakin I.V. (Zahodjakin, 2008) emphasizes that this progress of modern post-industrial society is ensured by economic growth, which can continue for decades under conditions of not only low, but also a negative rate of accumulation in its traditional sense.

\section{Conclusions}

The preconditions for the development of a modern intellectual economy have been developed within the framework of post-industrial theory and practical experience in the formation of post-industrial society.

As it was predicted by post-industrial theory creators, a mass consumer society gave rise to a service economy, and within its framework, the information sector of the economy began to develop at the fastest pace. At the same time, it can be stated that the traditional concept 
of "postindustrial economy" is getting out of use in scientific circulation. Today, it includes more specialized categories: "knowledge-based economy"; "service economy" (since the result of labor in a post-industrial society is mostly intangible products, i.e. services); innovative economy (intangible product, in fact, is innovative, and after it innovative material products appear); information economy (since information is the main resource and product); creative economy (the creative class and creative industries are growing at the fastest pace); sustainable (socio-environmentaleconomic) development.

In our view, the intellectual economy is a type of economic system that, being based on the intellectual capital of society in the conditions of development of modern information technologies and systems, uses, transforms, creates and disseminates information and knowledge in order to ensure the growth of social welfare, international competitiveness of countries and extended knowledge and innovation cycle formation. That is, knowledge is at the heart of the development of the economic system, and, at the same time, is the final product of this system in each cycle of reproduction of the socio-ecological-economic system.

The determining direction of the transformations in the intellectual economy is predominantly the creation and consumption of knowledge as a different type of intellectual property, including its materialized form with a high intellectual component. The fact that knowledge and information are not only used as an inexhaustible cognitive resource for the development of production, but also turn into the main types of consumption associated with personal development, as a means of renewing and building up this resource, is the key to the endless progress of the intellectual economy.

\section{References:}

Marshall, A. (1890). Principles of Economics. Eighth edition. London: Macmillan and Co., Ltd.

Schumpeter, J. (1911). The Theory of Economic Development. Oxford: Oxford University Press.

Coomaraswamy, A. (ed.) (1914). Essays in Post-Industrialism: A Symposium of Prophecy Concerning the Future of Society. London.

Penty, A. (1917). Old Worlds for New: A Study of Post-Industrial State. London.

Penty, A. (1922). Post-Industrialism. London.

Drucker, P. (1950). The New Society: The anatomy of the industrial order. NY: Harper \& Brothers.

Machlup, F. (1962). The Production and Distribution of Knowledge in the United Sttates. Princeton N.J.: Princeton University Press.

Riesman, D. (1958). Leisure and Work in Post-Industrial Society. Glencoe, no. 111, pp. 363-385.

Inozemcev, V. L. (2000). Sovremennoe postindustrial'noe obshhestvo: priroda, protivorechija, perspektivy [Modern post-industrial society: nature, contradictions, prospects]. Moscow: Logos. (in Russian)

Bell, D. (ed.) (1968). Toward the Year 2000. Work in Progress. Boston

Bell, D. (1973). The Coming Post-Industrial Society. N.Y.: Free Press.

Martin, W. J. (1995). The Global Information Society. Aldershot Aslieb Gower: Broofield.

Stoun'er, T. (1986). Informacionnoe bogatstvo: profil' postindustrial'noj jekonomiki [Information wealth: the profile of the post-industrial economy]. Moscow: Progress. (in Russian)

Masuda, Y. (1981). The Information Society as Post-Industrial Society. - Wash. DC: World Future Society.

Kastel's, M. (2000). Informacionnaja jepoha: jekonomika, obshhestvo i kul'tura [The Information Age: Economy, Society and Culture]. Moscow: GU VShJe. (in Russian)

Stehr, N. (1994). Knowledge Societies. London: Sage.

Kelly, K. (1998). New Rules for the New Economy. Ten Radical Strategies for a Connected World. N.Y.: Penguin Books. Skilbeck, M. (1964). Study Group in the Economics of Education, Residual Factor and Economic Growth. Paris: Organization for Economic Cooperation and Development.

Abramowitz, M. (1956). Resource and output trends in the United States since 1870. American Economic Review, no. 46, pp. 5-23.

Romer, P. M. (1986). Increasing returns and long-run growth. Journal of Political Economy, vol. 5, no. 94, pp. 1002-37. OECD (1996). The Knowledge-Based Economy. Paris: Organisation for Economic Cooperation and Development. AREC (2000). Towards knowledge-based economies in APEC. Singapore: AREC Secretariat.

Chartland, H. H. (2006). The competitiveness of nations in a global knowledge-based economy ( $\mathrm{PhD}$ thesis), Saskatchewan: University of Saskatchewan (unpublished).

Brinkley, I. (2006). Defining the knowledge economy. London: The Work Foundation.

Tapscott, D. (2014). The digital economy. Anniversary Edition: Rethinking promise and peril in the age of networked intelligence. New York: McGraw-Hill.

White, D. S., Gunasekaran, A., \& Ariguzo, G. (2012). The structural components of a knowledge-based economy. International Journal of Business Innovation and Research, vol. 4, no. 7, pp. 504-518. 
Shahrazad, H. (2017). Knowledge Economy: Characteristics and Dimensions. Management Dynamics in the Knowledge Economy, vol. 5, no. 2, pp. 203-225.

Ivanova, V.V. (2011). Ekonomika, zasnovana na znannjah, ta ekonomika znan': adekvatnist' vykorystannja kategorij [A knowledge-based economy and a knowledge economy: the adequacy of the use of categories]. Mechanism of Economy Regulation, no. 3, p. 47-54.

Androshhuk, G. A. (2006). Prognozirovanie innovacionnoj dejatel'nosti na osnove analiza aktivnosti global'nyh firm [Predicting innovation activity based on activity analysis of global firms]. Problems of Science, no. 5, pp. 40-47. Fedulova, L. I. (2009). Ekonomika znan' [Knowledge Economy]. Kyiv: NAS of Ukraine, Institute of Economics and Prediction. (in Ukrainian)

Gaponenko, A. L. (2010). Sovremennyj rynok znanij: ponjatie, uchastniki, formy [The modern knowledge market: concept, participants, forms]. Problems of the theory and practice of management, no. 6, p. 55-64.

Azhazha, M. A. (2007). Investycii' v osvitu jak faktor intelektual'nogo progresu [Investments in education as a factor of intellectual progress]. Social Perspective and Regional Development, no. 2, pp. 37-40.

Butnik-Sivers'kyj, O. B. (2007). Innovatyka ta intelektual'na ekonomika (teoretyko-metodologichnyj aspekt) [Innovation and Intellectual Economics (Theoretical and Methodological Aspect)]. Teorija i praktyka intelektual'noi' vlasnosti, no. 6, pp. 68-81.

Salihov, B. V., \& Letunov, D. A. (2008). Intellektual'naja jekonomika kak nravstvenno-jeticheskaja forma innovacionnogo razvitija [Intellectual economy as a moral and ethical form of innovative development]. Problemy sovremennoj jekonomiki, vol. 3, no. 27, pp. 108-111.

Maksimova, V. F. (2011). Smart (intellektual'naja) jekonomika: celi, zadachi i perspektivy [Smart (intellectual) economy: goals, objectives and prospects]. Otkrytoe obrazovanie, (electronic journal), no. 3. Retrieved from: https:// cyberleninka.ru/article/n/smart-intellektualnaya-ekonomika-tseli-zadachi-i-perspektivy/viewer (accessed 30 January 2020).

Zamlelyj, A. Ju. (2012). Formirovanie smart (intellektual'noj) jekonomiki: teorija i praktika [Formation of smart (intellectual) economy: theory and practice]. Sovremennye problemy nauki i obrazovanija, (electronic journal), no. 4. Retrieved from: https://www.science-education.ru/pdf/2012/4/176.pdf (accessed 30 January 2020).

Sabden, O. (ed.). Intellektual'naja jekonomika - tehnologicheskie vyzovy XXI veka Glaz'ev S. Ju., Armenkij A. E., Naumov E. A. (n.d.) [Intellectual Economics - Technological Challenges of the 21st Century]. (in Russian)

Tretjak, A. M., \& Kalganova, I. G. (2016). Do pytannja pro ekonomichnu sutnist' ponjattja innovacij ta innovacijnoi' dijal'nosti u sferi zemleustroju [On the question of the economic nature of the concept of innovation and innovation in land management]. Zemleustrij, kadastr $i$ monitoryng zemel' (electronic journal), no. 3, pp. 54-64. Retrieved from: http://nbuv.gov.ua/UJRN/Zemleustriy_2016_3_10 (accessed 30 January 2020).

Kondrashova-Didenko, V. (2009). Intelektual'no zorijentovana ekonomika [The intellectually oriented economy]. Visnyk Kyi'vs'kogo nacional'nogo universytetu imeni Tarasa Shevchenka. Ekonomika (electronic journal), no. 109, pp. 56-59. Retrieved from: http://nbuv.gov.ua/UJRN/VKNU_Ekon_2009_109_19 (accessed 30 January 2020). Mokyr, J. (2002). The Gifts of Athena: Historical Origin of the Knowle $\overline{d g e}$ Economy. Princeton \& Oxford: Princeton University Press.

New Zealand Bank (n.d.) Estimating the Value of Intellectual Capital in the Service Industry. NZ: New Zealand Banks. Retrieved from: http://aux.zicklin.baruch.cuny.edu/critical/html2/8037saharawat.html (accessed 30 January 2020). Nature (1999). Promises and Threats of the Knowledge-based Economy. Nature, vol. 397.

Druker, P. F. (2001). Zadachi menedzhmenta $v$ XXI veke [Management tasks in the XXI century]. Moscow: Vil'jams. (in Russian)

Florida, R. (2002). The rise of the creative class N.Y.: The Prseus Books Group

Government Publications (2008). Building Ireland's Smart Economy. A Framework for Sustainable Economic Renewal. Dublin: Government Publications.

Preston, P., \& Sparviero, S. (2010). Smart if Small Economies? Ireland's Strategy in Comparative Frame. Dublin: Dublin City University.

Brinkley, Ia. (2008). Knowledge economy: How Knowledge is Reshaping the Economic Life in Nations. London: The Work Foundation.

Kvasnij, L. G., \& Shherbak, O. Ja. (2013). Rozvytok ekonomiky znan' jak bezperervnyj proces investuvannja u ljuds'kyj kapital [The development of the knowledge economy as a continuous process of investing in human capital]. Visnyk Nacional'nogo universytetu "L'vivs'ka politehnika". Menedzhment ta pidpryjemnyctvo v Ukrai'ni: etapy stanovlennja i problemy rozvytku (electronic journal), no. 767, pp. 206-211. Retrieved from: http://nbuv.gov.ua/ UJRN/VNULPM_2013_767_31 (accessed 30 January 2020).

Zahodjakin, I. V. (2008). Postindustrial'naja jekonomika - chto znachit jeto ponjatie v sovremennom mire? [Postindustrial economy - what does this concept mean in the modern world?]. Kreativnaja jekonomika, (electronic journal), no. 1. Retrieved from: https://cyberleninka.ru/article/n/postindustrialnaya-ekonomika-chto-znachiteto-ponyatie-v-sovremennom-mire/viewer (accessed 30 January 2020). 